Gut, 1986, 27, 521-527

\title{
Lactose digestion by human jejunal biopsies: the relationship between hydrolysis and absorption
}

\author{
D J DAWSON, R W LOBLEY, P C BURROWS, V MILLER, AND R HOLMES \\ From the University Department of Gastroenterology, Manchester Royal Infirmary and Department of \\ Paediatric Gastroenterology, Booth Hall Hospital, Manchester.
}

SUMMARY The relationship between lactose hydrolysis and absorption of released glucose was investigated by determining the kinetics of lactose digestion by jejunal biopsies incubated in vitro. Lactase activity in intact biopsies correlated with conventional assay of tissue homogenates $(\mathrm{r}=0.85, \mathrm{p}<0.001)$, and glucose uptake from $28 \mathrm{mM}$ lactose was directly proportional to lactase activity $(r=0.95, p<0.001)$ in 21 subjects with normal lactase levels, six with hypolactasia (primary or secondary to coeliac disease) and two with lactose intolerance but normal lactase activity. Kinetic analysis at $0 \cdot 56-56 \mathrm{mM}$ lactose in five normal subjects showed saturable kinetics for hydrolysis (app $\mathrm{K}_{\mathrm{m}}=33.9 \pm 2 \cdot 2 \mathrm{mM}$; app $\mathrm{V}_{\max }=26.5 \pm 1 \cdot 1 \mathrm{nmol} / \mathrm{min} / \mathrm{mg}$ dry weight) but glucose uptake could be fitted to a model either of saturable uptake (app $\mathrm{K}_{\mathrm{t}}=47 \cdot 2 \pm 0.3 \mathrm{mM}$; app $\left.J_{\max }=14 \cdot 1 \pm 0 \cdot 2 \mathrm{nmol} / \mathrm{min} / \mathrm{mg}\right)$ or saturable uptake plus a linear component $\left(\operatorname{app} \mathrm{K}_{\mathrm{t}}=21 \cdot 3 \pm\right.$ $1 \cdot 15 ;$ app $J_{\max }=4.59 \pm 0 \cdot 12 ;$ app $\left.K_{d}=0.093 \pm 0 \cdot 010 \mathrm{nmol} / \mathrm{min} / \mathrm{mg} / \mathrm{mM}\right)$. The proportion of glucose taken into the tissue did not significantly exceed $50 \%$ of the total released at any lactose concentration suggesting the lack of an efficient capture mechanism for the released glucose. The results suggest that lactose hydrolysis is the rate limiting step in the overall absorption of glucose from lactose in vitro, and that the relationship between hydrolysis and absorption is the same in normal subjects and in hypolactasic subjects.

The relationship between lactose hydrolysis and absorption of the released monosaccharides is not fully understood. From perfusion studies with lactose and an equimolar mixture of glucose and galactose, Gray and Santiago ${ }^{1}$ concluded that hydrolysis was rate limiting to the overall process of lactose absorption. McMichael, Webb and Dawson, ${ }^{2}$ however, found no correlation between mucosal lactase activity in vitro and lactose hydrolysis in vivo, and concluded that hydrolysis was rate limiting only when disaccharidase activity was very low.

Lactose intolerance correlates poorly with indirect measures of lactase activity - for example, the oral lactose tolerance test, ${ }^{3}$ and also with mucosal lactase activity measured directly. ${ }^{4-6}$ This may be explained by variations in the load of lactose presented to the intestine, variable gastric emptying and intestinal motility, and differences in compensa-

Address for correspondence: Dr R Holmes, University Department of Gastroenterology, Manchester Royal Infirmary, Oxford Road, Manchester, M13 9WL.

Received for publication 27 August 1985 tory mechanisms of the colon ${ }^{7}$ but there remains a possibility that lactase activity measured in mucosal homogenates does not accurately reflect the ability of intact tissue to digest lactose.

In this study, lactose absorption by jejunal biopsies has been investigated using a technique which measures initial rates of monosaccharide uptake. ${ }^{8}$ We have compared lactose hydrolysis in intact tissue with that in tissue homogenates and also determined the relationship between lactose hydrolysis and subsequent absorption of glucose in the same tissue.

\section{Methods}

\section{PATIENTS}

Fourteen adults and 15 children who were undergoing routine investigation for gastrointestinal symptoms, short stature or failure to thrive were studied. The final diagnoses, clinical details and lactase activities are given in Table 1. Lactase deficiency (activity $<0.65 \mathrm{U} / \mathrm{g}$ wet weight determined using non-incubated homogenised tissue) was found 
Table 1 Clinical details and lactase activities of the patients

\begin{tabular}{|c|c|c|c|c|}
\hline Patient & Age (yrs) & Sex & $\begin{array}{l}\text { Lactase activity } \\
\text { (normal }>1.0 \mathrm{U} / \mathrm{g} \text { wet } w t) \\
\text { (hypolactasia }<0.65 \mathrm{U} / \mathrm{g} \text { wet wt) }\end{array}$ & Diagnosis \\
\hline \multicolumn{5}{|l|}{ Adults } \\
\hline 1 & 44 & $\mathrm{~F}$ & $10 \cdot 44$ & Irritable bowel syndrome \\
\hline 2 & 37 & $\mathrm{~F}$ & $9 \cdot 02$ & Irritable bowel syndrome \\
\hline 3 & 45 & $\mathrm{~F}$ & $5 \cdot 35$ & Irritable bowel syndrome \\
\hline 4 & 34 & $\mathbf{F}$ & $9 \cdot 97$ & Irritable bowel syndrome \\
\hline 5 & 20 & $\mathbf{F}$ & $4 \cdot 56$ & Irritable bowel syndrome \\
\hline 6 & 20 & $\mathbf{F}$ & $4 \cdot 88$ & Irritable bowel syndrome \\
\hline 7 & 58 & $\mathbf{F}$ & $2 \cdot 83$ & Irritable bowel syndrome \\
\hline 8 & 59 & $\mathbf{F}$ & $6 \cdot 50$ & Pernicious anaemia \\
\hline 9 & 29 & $\mathbf{F}$ & $2 \cdot 41$ & Congenital short stature \\
\hline 10 & 55 & $\mathbf{M}$ & $8 \cdot 59$ & Post vagotomy diarrhoea \\
\hline 11 & 61 & $\mathbf{F}$ & $2 \cdot 36$ & Pancreatic steatorrhoea \\
\hline 12 & 21 & $\mathbf{M}$ & $3 \cdot 29$ & Crohn's disease \\
\hline 13 & 49 & $\mathbf{M}$ & $0 \cdot 61$ & Hypolactasia \\
\hline 14 & 68 & $\mathbf{F}$ & $0 \cdot 00$ & Untreated coeliac disease \\
\hline \multicolumn{5}{|c|}{ Children } \\
\hline 15 & 11 & $\mathbf{M}$ & $0 \cdot 86$ & Diarrhoea \\
\hline 16 & $17 \mathrm{mths}$ & $\mathbf{M}$ & $1 \cdot 32$ & Previous gastroenteritis \\
\hline 17 & 15 & $\mathbf{F}$ & $7 \cdot 83$ & Abdominal pain \\
\hline 18 & 11 & $\mathbf{M}$ & $3 \cdot 22$ & Congenital short stature \\
\hline 19 & 8 & $\mathbf{M}$ & $3 \cdot 56$ & Abdominal pain and diarrhoea \\
\hline 20 & 3 & $\mathbf{M}$ & $0 \cdot 96$ & Failure to thrive \\
\hline 21 & 3 & $\mathbf{F}$ & $9 \cdot 31$ & Failure to thrive \\
\hline 22 & $31 / 2$ & $\mathbf{M}$ & 4.92 & Previous gastroenteritis \\
\hline 23 & 6 & $\mathbf{F}$ & $2 \cdot 10$ & Diarrhoea \\
\hline 24 & 14 & $\mathbf{F}$ & $0 \cdot 04$ & Coeliac disease in relapse \\
\hline $25^{*}$ & 8 & $\mathbf{M}$ & $5 \cdot 58$ & Lactose intolerance \\
\hline $26^{*}$ & 12 & $\mathbf{F}$ & $1 \cdot 56$ & Lactose intolerance \\
\hline $27^{*}$ & 14 & $\mathbf{M}$ & $1 \cdot 37$ & Lactose intolerance \\
\hline $28^{*}$ & 8 & $\mathrm{~F}$ & $4 \cdot 21$ & Lactose intolerance \\
\hline $29^{*}$ & 4 & $\mathbf{M}$ & $1 \cdot 24$ & Lactose intolerance \\
\hline
\end{tabular}

* These patients had abnormal breath hydrogen tests and stool chromatograms following an oral lactose load.

in two patients with coeliac disease (nos 14 and 24) and one with acquired lactose intolerance (no. 13). Borderline lactase deficiency $(0 \cdot 65-1 \cdot 0 \mathrm{U} / \mathrm{g}$ wet weight) was found in two patients (nos 15 and 20) who had no evidence of lactose intolerance and normal breath hydrogen tests. Two children (nos 16 and 22) were thought to have had transient lactose intolerance due to gastroenteritis but were asymptomatic and had normal lactase activity at the time of biopsy. Five children (nos 25-29) had continuing lactose intolerance with abnormal breath hydrogen tests and positive stool chromatograms for sugars after an oral lactose load, but had normal lactase levels by conventional assay; three of these were subsequently shown to be hypolactasic. Histology was normal in all patients except those with coeliac disease who showed partial villous atrophy. This study was approved by the ethical committees of the Central and North Manchester Health Authorities.

\section{BIOPSY INCUBATION}

Peroral jejunal biopsies were obtained by Crosby capsule and immediately transferred to ice cold Krebs-Ringer solution, $\mathrm{pH} 7 \cdot 4$, containing $20 \mathrm{mM}$ HEPES and $1 \mathrm{mg} / \mathrm{ml}$ bovine serum albumin (BSA), and gassed with $95 \% \mathrm{O}_{2} / 5 \% \mathrm{CO}_{2}$. Single biopsies were subdivided, one portion examined histologically, and one blotted and frozen at $-20^{\circ} \mathrm{C}$ for disaccharidase analysis. The remaining tissue specimens were pre-incubated in the same buffer for 10 minutes, then transferred to $2 \mathrm{ml}$ of buffer containing $28 \mathrm{mM}$ lactose, (labelled with $5 \mu \mathrm{Ci}\left[1-{ }^{14} \mathrm{C}-\mathrm{D}\right.$ glucose $]$-lactose), and $7 \cdot 5 \mu \mathrm{Ci}\left[{ }^{3} \mathrm{H}\right]$-polyethylene glycol 4000 (PEG) for incubation $(10 \mathrm{~min})$ at $37^{\circ} \mathrm{C}$ in $25 \mathrm{ml}$ conical flasks gassed with $95 \% \mathrm{O}_{2} / 5 \% \mathrm{CO}_{2}$ and shaken at $200 \mathrm{cycles} / \mathrm{min}$.

In five adults, multiple biopsies were taken using the Quinton-Rubin hydraulic instrument and subdivided to yield tissue specimens for incubation in buffer containing $0.56-56 \mathrm{mM}$ lactose, $112 \mathrm{mM}$ 
$\mathrm{Na}^{+}$and sufficient mannitol to maintain the osmolality at $310 \mathrm{mOsm} / \mathrm{kg}$.

After incubation $(10 \mathrm{~min})$, the medium was removed by suction filtration and collected separately. The biopsy specimens, retained on membrane filters (Schleicher and Schuell ST69, pore diameter $1.2 \mu \mathrm{m})$, were washed twice with $20 \mathrm{ml}$ ice cold $150 \mathrm{mM}$ sodium chloride, transferred individually to conical PTFE-glass homogenisers, and snapfrozen at $-50^{\circ} \mathrm{C}$ to prevent metabolism. Each piece was subsequently homogenised in $1.6 \mathrm{ml}$ of water and aliquots used to measure:

(1) Tissue dry weight was determined by drying a $400 \mu \mathrm{l}$ aliquot on to a preweighed glass fibre disc (Whatman GF/D, $2.5 \mathrm{~cm}$ diameter). Discs were dried at $70^{\circ} \mathrm{C}$ over $\mathrm{P}_{2} \mathrm{O}_{5}$ and weighed on a microbalance against a tared reference disc.

(2) Tissue radioactivity was determined by dual channel liquid scintillation counting of a $400 \mu \mathrm{l}$ aliquot dissolved in $2.5 \mathrm{ml}$ tissue solubilizer (NCS, Amersham International) before addition of a toluene based scintillant containing $4 \mathrm{~g} / 1$ 2,5-diphenyl oxazole and $250 \mathrm{mg} / \mathrm{l}$ 1,4-di-2-(5-phenyloxazolyl)benzene. Pre-incubation medium counts were measured using $20 \mu \mathrm{l}$ aliquots plus $380 \mu \mathrm{l}$ of water dissolved in NCS.

(3) Sugar assay: boiled aliquots of medium and tissue were analysed fluorimetrically for glucose and galactose using hexokinase/glucose-6-phosphate dehydrogenase/NAD ${ }^{9}$ or galactose dehydrogenase/NADP. ${ }^{10}$ Lactose was assayed in tissue homogenates only using $\beta$-galactosidase/galactose dehydrogenase/NADP. ${ }^{10}$

(4) Brush-border enzymes: $225 \mu \mathrm{l}$ aliquots of homogenate were diluted four-fold in MOPSmannitol buffer containing $2 \%$ BSA and frozen at $-20^{\circ} \mathrm{C}$ for subsequent determination of lactase by a fluorimetric adaptation of the method of Dahlqvist, ${ }^{11}$ using 4-hydroxyphenylacetic acid in place of $o$ dianisidine; $\beta$-fucosidase, $\alpha$-glucosidase and alkaline phosphatase by fluorimetric assays with the appropriate 4-methylumbelliferyl compounds as substrates; and protein by a fluorescamine method. ${ }^{12}$ Incubation media were analysed for $\beta$-fucosidase, alkaline phosphatase and $\alpha$-glucosidase.

Kinetic parameters were derived with the aid of a curve fitting program available from the CERN computer program library. ${ }^{13}$ The data were fitted to models of saturable uptake (Michaelis-Menten kinetics) with or without a linear component of uptake.

\section{CALCULATION}

Intracellular glucose uptake was calculated from the equation: glucose uptake

$$
\begin{gathered}
=\left(\frac{\text { tissue }{ }^{14} \mathrm{C} \mathrm{dpm}}{\text { medium }{ }^{14} \mathrm{C} \mathrm{dpm} / \mu \mathrm{l}}-\frac{\text { tissue }{ }^{3} \mathrm{Hdpm}}{\text { medium }{ }^{3} \mathrm{Hdpm} / \mu \mathrm{l}}\right) \\
\times \text { sugar concentration }(\mathrm{mM})
\end{gathered}
$$

For lactose incubations, this assumes that all intracellular ${ }^{14} \mathrm{C}$ activity (obtained by correcting total ${ }^{14} \mathrm{C}$ activity for that present in the PEG space) is derived from glucose, and that lactose does not significantly penetrate this space. This assumption was checked by comparing the radiometrically measured uptake of glucose with the glucose measured fluorimetrically in 119 tissue specimens. There was good correlation between the two measures of glucose $(r=0.96, p<0.001)$ and the slope of the line was not significantly different from 1 , implying that the assumption is correct. Furthermore, fluorimetric measurements of tissue lactose did not exceed those expected from the PEG space.

Lactase activity of intact tissue was calculated from the radiometrically determined intracellular glucose and the fluorimetrically determined glucose in the medium as follows:-

$$
\underset{\text { lactase activity }}{(\mathrm{U} / \mathrm{g} \text { dry wt })}=\frac{\begin{array}{c}
\text { intracellular glucose }(\mathrm{nmol}) \\
\text { medium glucose }(\mathrm{nmol})
\end{array}}{\begin{array}{c}
\text { incubation time }(\mathrm{min}) \\
\text { dry weight }(\mathrm{mg})
\end{array}} \times
$$

\section{Results}

\section{LACTASE ACTIVITY IN INTACT TISSUE}

The histology of biopsies was normal after incubation and the specific activities (U/g dry weight) of all brush-border enzymes measured were not significantly changed compared with paired unincubated biopsies from the same individuals. Preliminary experiments showed that lactose hydrolysis was linear throughout the incubation period and was not significantly different when calculated in terms of either galactose or glucose released. Tissue uptakes of glucose and galactose were also linear with time but at low lactose concentrations, uptake of galactose was at the limits of fluorimetric detection and thus radiometric measurements of glucose uptake were used in the kinetic studies.

The lactase activity of intact tissue and of homogenates of the same tissue specimens after incubation were compared in 23 subjects (Fig. 1). There was a highly significant correlation between the two measures of lactase activity $(r=0 \cdot 84, p<0 \cdot 001)$ but in intact tissue we detected only $25 \%$ of the activity measured in homogenised tissue. Control experi- 


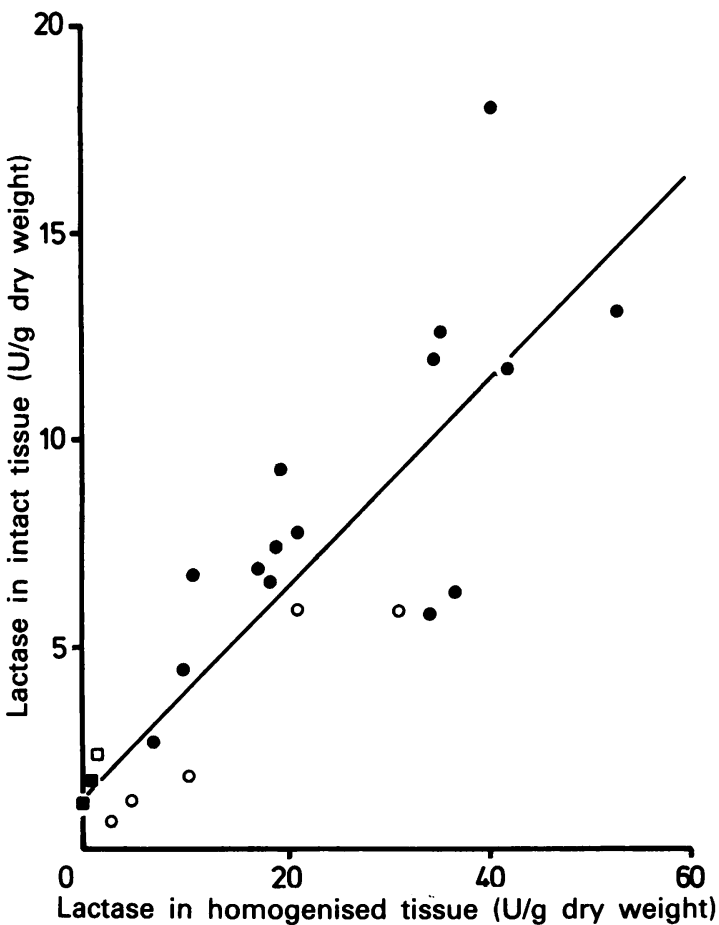

Fig. 1 Relationship between lactase activity in 23 specimens incubated intact and in the same specimens incubated after homogenisation. (O), patients with normal histology and disaccharidase activity; (O), patients 25-29 with lactose intolerance; (匚), patients 14 and 24 with coeliac disease; ( $\square$ ), patient 13 with hypolactasia. Line $(y=$ $0 \cdot 25 x+1 \cdot 30$ ) is the least squares fit to the data and the intercept is not significant.

ments where tissue homogenates were assayed at $\mathrm{pH}$ 7.4 and at $\mathrm{pH} 6.0$ showed the same reduction in lactase activity at the lower $\mathrm{pH}$.

The lactase activity measured in intact tissue in normolactasic subjects ranged from 2.7 to $18.0 \mathrm{U} / \mathrm{g}$ dry weight. The two patients with coeliac disease and one with acquired alactasia were hypolactasic by the assay of intact tissue. Of the five subjects with clinical lactose intolerance but previously normal lactase activity, three were hypolactasic by assay of intact tissue and repeat conventional assay of tissue homogenates confirmed this; the other two were normolactasic in both assays (Fig. 1). The relationship between assay of intact tissue and assay of tissue homogenates was no different for these eight subjects than for the normolactasic subjects (Fig. 1).

\section{KINETICS OF LACTOSE DIGESTION}

The concentration dependence of both lactose hydrolysis and glucose absorption from lactose determined in five normal subjects was curvilinear with lactose hydrolysis exceeding glucose absorption at all lactose concentrations (Fig. 2). The curve fitting programme showed that both lactose hydrolysis and glucose uptake could be fitted with equal precision either to a model of single saturable

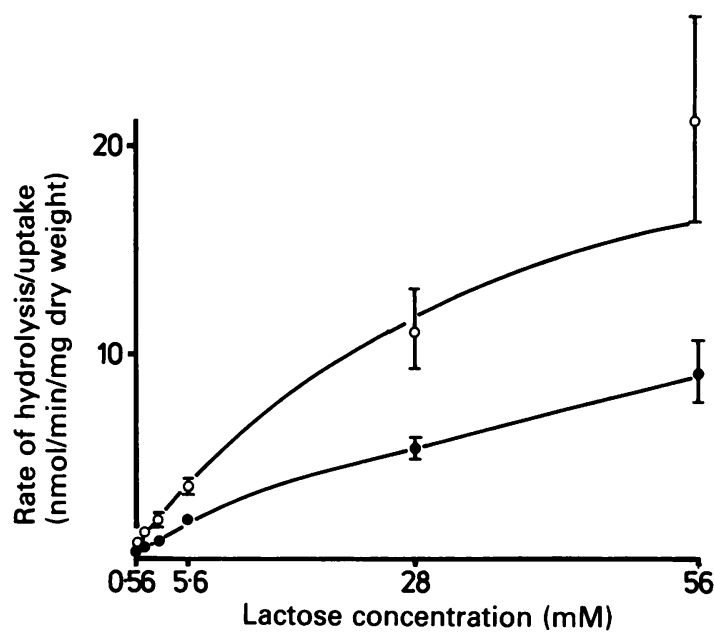

Fig. 2 Concentration dependence of lactose hydrolysis (O) and uptake of glucose from lactose (O) in specimens from five normal adults. Values are the mean $( \pm 1 S$.E.) hydrolysis/uptake rate at lactose concentrations between 0.56-56 mM. The curves are the computer-derived best fit to the data.

Table 2 Kinetic constants (means $\pm 1 S E$ ) for lactose hydrolysis and glucose uptake derived from the data in Figure 2 by a computerised curve-fitting program. ${ }^{13}$

\begin{tabular}{llll}
\hline & $\begin{array}{l}a p p K m / K t \\
(m M)\end{array}$ & $\begin{array}{l}\text { app Vmax/Jmax } \\
(\text { nmoles/min/mg) }\end{array}$ & $\begin{array}{l}\text { app Kd } \\
(\text { nmoles/min/mg/mM) }\end{array}$ \\
\hline $\begin{array}{l}\text { Lactose hydrolysis } \\
\quad \text { Single component } \\
\quad \text { Two component }\end{array}$ & $33 \cdot 9 \pm 2 \cdot 2$ & $26 \cdot 5 \pm 1 \cdot 1$ & - \\
Glucose uptake & $1 \cdot 04 \pm 1 \cdot 31$ & $1 \cdot 16 \pm 0 \cdot 79$ & $0 \cdot 38 \pm 0 \cdot 07$ \\
$\quad$ Single component & & & \\
Two component & $47 \cdot 2 \pm 0 \cdot 3$ & $14 \cdot 1 \pm 0 \cdot 2$ & - \\
\hline
\end{tabular}


uptake or to one of single saturable uptake plus a linear component. The derived kinetic constants are given in Table 2: those for two component lactose hydrolysis appear physiologically and biochemically improbable.

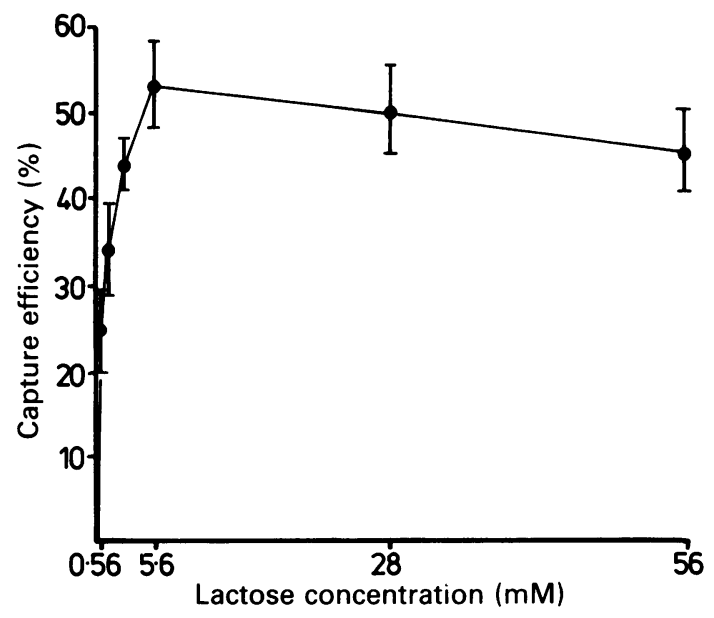

Fig. 3 Capture efficiency for glucose uptake from lactose at different lactose concentrations, calculated as intracellular/total glucose for the same subjects as in Figure 2 (see Methods). There is no significant difference between the values from $2 \cdot 8$ to $56 \mathrm{mM}$ lactose.

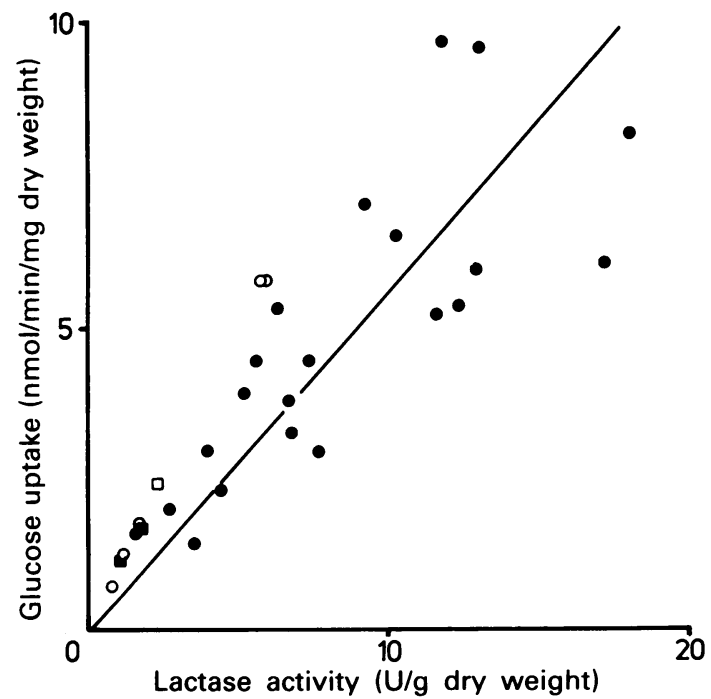

Fig. 4 Relationship between uptake of glucose from lactose and lactase activity in 29 biopsies incubated intact in $28 \mathrm{mM}$ lactose. The symbols are described in the legend to Figure 1. the line $(y=0.55 x)$ is the least squares fit to the data forced through the origin.
The proportion of the total glucose released by hydrolysis which was taken up by the tissue increased with lactose concentration up to $5.6 \mathrm{mM}$ and above that remained constant (Fig. 3).

Figure 4 shows that in biopsies incubated at a lactose concentration of $28 \mathrm{mM}$, uptake of glucose was directly related to tissue lactase activity $(r=0.95, p<0.001)$. This relationship was true for normal subjects, those with hypolactasia and those with clinical lactose intolerance.

\section{Discussion}

The use of human jejunal biopsies to study sugar absorption has largely been confined to the study of monosaccharide uptake,$^{14-17}$ although London et al investigated lactose metabolism in biopsies using a steady-state incubation technique. ${ }^{18}$ The method described here has been validated previously for the measurement of initial rates of monosaccharide absorption ${ }^{8}$ and the present results show that it is applicable to the measurement of lactose hydrolysis, thus enabling both processes to be measured in the same piece of tissue.

The assumption that all intracellular ${ }^{14} \mathrm{C}$-radioactivity is due to glucose requires comment, as small amounts of lactose have been shown to penetrate the mucosa in vivo, ${ }^{19}$ and penetration via the cut edges of the tissue will occur in vitro. In practice, such penetration is unlikely to be significant because of the multiplying effects of villi and microvilli, which produce a mucosal to serosal surface area ratio of the order of 200:1. ${ }^{20}$ Furthermore, frozen section autoradiography has confirmed that sugars enter the mucosa predominantly at the tips of the villi. ${ }^{21}$ The observation that no intracellular lactose could be detected in the current study is consistent with the results of London et al ${ }^{18}$ who found no intracellular accumulation during incubation of biopsies for up to 90 minutes. It is likely that in the 10 minute incubation of our experiments, any lactose permeation would have been below the limits of detection or compensated by the extracellular fluid space correction.

Our results might have been biased by metabolism of absorbed glucose. However, the rate of lactose hydrolysis in control experiments was the same when expressed either as galactose or glucose released. Because galactose is poorly metabolised, this suggests no significant loss of glucose from the overall system. Thus glucose metabolism appears negligible, in accord with the results of Desjeux et al who used a similar in vitro technique. ${ }^{17}$

The kinetics of lactose hydrolysis have not previously been studied in intact jejunal biopsies. Our results suggest that hydrolysis follows Michaelis- 
Menten kinetics with a $K_{\mathrm{m}}$ of $33.9 \pm 2.2 \mathrm{mM}$ comparable with that of $17-23 \mathrm{mM}$ and $21 \mathrm{mM}$ obtained for purified preparations of human lactase. 22 Lactose concentrations in this study were chosen to give maximum information about the uptake of released glucose, and the majority of concentrations lie below the estimated $K_{m}$ for lactose hydrolysis which must therefore remain approximate. This distribution of concentrations also explains why it is possible to fit a model of twocomponent hydrolysis to the data. The kinetic constants thus obtained, however, have little physiological meaning and bear no relationship to $\mathrm{K}_{\mathrm{m}}$ values for purified lactase..$^{22}{ }^{23}$ This emphasises the need to interpret computer models of kinetic data with caution. ${ }^{24}$

The kinetics of uptake of glucose released by hydrolysis could be fitted to a model of a single saturable transport system either with or without a linear uptake system. Incubation at higher concentrations might help to distinguish between these possibilities, but we favour the two component model as this has been demonstrated for glucose uptake when presented as the monosaccharide in rat in vivo $o^{25}$ and in man in vivo ${ }^{26}$ and in vitro. ${ }^{816}$ Furthermore, the apparent $\mathrm{J}_{\max }$ derived for glucose uptake from lactose assuming a saturable component only $(14 \cdot 1 \pm 0 \cdot 2 \mathrm{nmol} / \mathrm{min} / \mathrm{mg})$ was greater than that which we have previously observed for the active component of glucose uptake when presented as the monosaccharide $(8 \cdot 4 \pm 1 \cdot 1 \mathrm{nmol} / \mathrm{min} / \mathrm{mg}){ }^{8}$ which is difficult to explain in kinetic terms.

A number of additional factors might influence the relationship between the amount of lactose hydrolysed and glucose uptake. In the current study, diffusional effects were not significant because a high shaking rate was chosen to minimise the unstirred water layer. ${ }^{27}$ Significant galactose inhibition of transport was also unlikely because, although the galactose concentration present at the glucose transporting site in this tissue could not be measured, if one assumes a $K_{i}$ for galactose of $10 \mathrm{mM}$ (its previously derived $K_{t}$ value ${ }^{28}$ ) then a steady-state galactose concentration of $100 \mathrm{mM}$ would be necessary to account for the change in the previously observed $\mathrm{K}_{\mathrm{t}}$ for glucose from $1.81 \mathrm{mM}^{8}$ to that of $21.3 \mathrm{mM}$ found in this study. From the rate of hydrolysis depicted in Figure 2, we calculate that this concentration could be achieved only at the end of 10 minute incubations in $56 \mathrm{mM}$ lactose and assuming that no galactose was absorbed by the tissue, conditions which were not present in the current study. Furthermore, because the time course of glucose uptake remained linear throughout the incubation period, galactose released by hydrolysis was not significantly inhibitory to uptake.
Theoretically, glucose uptake from lactose could also be affected by the efficiency of capture of the monosaccharides. Crane,$^{29}$ and Parsons and Pritchard ${ }^{30}$ have postulated a spatial arrangement of the brush border such that after disaccharide hydrolysis, translocation of hexose into the tissue is favoured rather than its back diffusion to the medium. Our study lends no support to this concept for lactose hydrolysis in vitro as at low concentrations, efficiency of glucose capture was low and rose to a maximum of only $50 \%$ at $5.6 \mathrm{mM}$, thereafter remaining more or less constant. There was thus an equal chance of back diffusion to the medium and no favoured delivery to the glucose transport site.

Although changes in capture efficiency may affect uptake at low lactose concentrations, it seems likely from our results that glucose uptake from lactose is determined primarily by the rate of lactose hydrolysis because Figure 4 clearly shows that at a given lactose concentration glucose uptake was directly related to the lactase activity of the tissue. Furthermore, if lactose hydrolysis is rate limiting to glucose absorption from lactose, then analysis of the active glucose transport step alone should yield kinetic parameters closely akin to those of lactose hydrolysis. ${ }^{31}$ Thus the app $K_{t}$ of glucose uptake $(21.3 \mathrm{mM})$ was in broad agreement with the app $\mathrm{K}_{\mathrm{m}}$ of lactose hydrolysis $(33.9 \mathrm{mM})$.

Our results refute the hypothesis that lactase activity measured in mucosal homogenates does not reflect the ability of intact tissue to hydrolyse lactose. Although in intact tissue we measured only $25 \%$ of the activity in tissue homogenates, this was because of the higher $\mathrm{pH}$ of the assay necessary for maintainence of tissue integrity and is consistent with the known $\mathrm{pH}$ profile for brush border lactase. ${ }^{22}{ }^{23}$ The important point is that the relationship between the two assays of lactase (intact $v s$ homogenised tissue) was the same in the normolactasic subjects, those with hypolactasia (primary or secondary), and in those with lactose intolerance of uncertain aetiology but with normal lactase levels. Furthermore, the relationship between the uptake of glucose from lactose and tissue lactase activity was also similar in these groups. Thus, the explanation for the poor correlation between lactose intolerance and mucosal lactase activity, ${ }^{4-6}$ does not lie in a functional disorder of the lactase in the brush border membrane.

We are grateful to the British Digestive Foundation for the award of the Markland Research Fellowship to D J Dawson; to the Mason Medical Research Foundation and the Research Grants Committee, Central Manchester Health Authority for financial support; to Mrs D E A Dawson for preparing the 
figures; and to Mrs S Lamb for secretarial assistance. Part of this work has been presented to the European Society of Comparative Physiology and Biochemistry, Bielefield, September 1982, and to the British Society of Gastroenterology, London, April 1983.

\section{References}

1 Gray GM, Santiago NA. Disaccharide absorption in normal and diseased human intestine. Gastroenterology 1966; 57: 489-98.

2 McMichael HB, Webb J, Dawson AM. The absorption of maltose and lactose in man. Clin Sci 1967; 33: $135-45$.

3 Newcomer AD, McGill DB. Lactose tolerance tests in adults with normal lactase activity. Gastroenterology 1966; 50: 340-6.

4 Dunphy JV, Littman A, Hammond JB, Forstner G, Dahlquist $A$, Crane RK. Intestinal lactase deficit in adults. Gastroenterology 1965; 49: 12-21.

5 Harrison M, Walker-Smith JA. Reinvestigation of lactose intolerant children: lack of correlation between continuing lactose intolerance and small intestinal morphology, disaccharidase activity and lactose tolerance tests. Gut 1977; 18: 48-52.

6 Editorial: lactose malabsorption and lactose intolerance. Lancet 1979; 2: 831-2.

7 Phillips SF. Lactose malabsorption and gastrointestinal function: effects on gastrointestinal transit and the absorption of other nutrients. In: Paige DM, Bayless TM. Lactose digestion: clinical and nutritional implications. Baltimore: John Hopkins University Press, 1981: 51-7.

8 Dawson DJ, Holmes R, Lobley RW. Intestinal absorption by human jejunal biopsies: uptake of glucose. $J$ Physiol 1982; 332: 101-2P.

9 Bergmeyer HU, Bernt E, Schmidt F, Stork H. DGlucose: determination with hexokinase and glucose-6phosphate dehydrogenase. In: Bergmeyer HU, ed. Methods of enzymatic analysis. New York: Verlag Chemie, Weinheim/Academic Press, 1974: 1198-1201.

10 Kurz G, Wallenfels $\mathrm{K}$. Lactose and other $\beta$-galactosidases. In: Bergmeyer HU, ed. Methods of enzymatic analysis. New York: Verlag Chemie, Weinheim/ Academic Press, 1974: 1180-4.

11 Dahlqvist A. Assay of intestinal disaccharidases. Anal Biochem 1968; 22: 99-107.

12 Bohlen P, Stein S, Dairman W, Udenfriend S. Fluorometric assay of proteins in the nanogram range. Ann Biochem Biophys 1973; 155: 213-20.

13 James F, Roos M. Programs D506 and D516. CERN Computer 7600. Geneva: Program Library, 1971.

14 Elsas LJ, Hillman RE, Patterson JH, Rosenberg LE. Renal and intestinal hexose transport in familial glucose-galactose malabsorption. J Clin Invest 1970; 49: 576-85.

15 Beck IT, Dinda PK, Da Costa LR, Beck M. Sugar absorption by small bowel biopsy samples from patients with primary lactase deficiency and with adult coeliac disease. Am J Dig Dis 1976; 21 : 946-52.

16 Thomson ABR, Weinstein WM. Transport kinetics of D-glucose in human small intestinal mucosa: rate constants in histologically normal and abnormal mucosal biopsies. Dig Dis Sci 1979; 24: 442-8.

17 Grasset E, Heyman M, Dumontier AM, Lestradet H, Desjeux JF. Possible sodium and D-glucose cotransport in isolated jejunal epithelium of children. Paediatr Res 1979; 13: 1240-6.

18 London DR, Cuatrecasas P, Birge SJ, Segal S. Metabolism of lactose by intestinal mucosa from normal and lactase-deficient subjects. Br Med J 1967; 1: 524-6.

19 Menzies IS. Absorption of intact oligosaccharides in health and disease. Biochem Soc Trans 1974; 2: 1042-7.

20 Trier JS, Madara JL. Functional morphology of the mucosa of the small intestine. In: Johnson, LR ed. Physiology of the gastrointestinal tract. New York: Raven Press, 1981, 925-63.

21 Stirling CE, Schneider AJ, Wong M-D, Kinter WB. Quantitative radioautography of sugar transport in intestinal biopsies from normal humans and a patient with glucose-galactose malabsorption. J Clin Invest 1972; 52: 438-51.

22 Asp NG, Dahlqvist A, Koldovsky O. Human small intestinal $\beta$-galactosidases. Separation and characterisation of one lactase and one hetero- $\beta$-galactosidase. Bichem J 1969; 114: 349-51.

23 Skovjberg $\mathrm{H}$, Sjostrom $\mathrm{H}$, Noren O. Purification and characterisation of amphiphilic lactase/phlorizin hydrolase from human small intestine. Eur J Biochem 1981; 114: 653-61.

24 Gardner MLG, Atkins GL. Kinetic analysis of transport processes in the intestine and other tissues. Clin Sci 1982; 63: 405-14.

25 Debnam ES, Levin RJ. An experimental method of identifying and quantifying the active transfer electrogenic component from the diffusive component during sugar absorption measured in vivo. J Physiol 1975; 246: 181-96.

26 Sandle GI, Lobley RW, Holmes R. Maltose hydrolysis and absorption in the human jejunum. Digestion 1982; 24: $137-45$.

27 L'Herminier M, Alvarado F. Virtual elimination of the interference of unstirred water layers on intestinal sugar transport kinetics by use of the tissue accumulation method at appropriate shaking rates. Pflugers Arch 1981 389: 155-8.

28 Dawson DJ, Holmes R, Lobley RW. Monosaccharide absorption by human jejunal biopsies: anomalous behaviour of galactose. J Physiol 1983; 339: 54P.

29 Crane RK. Structural and functional organisation of an epithelial cell brush border. In: Warren KB, ed. Symposia of the International Society for Cell Biology. New York: Academic Press, 1966: 71-102.

30 Parsons DS, Prichard JS. Relationships between disaccharide hydrolysis and sugar transport in amphibian small intestine. J Physiol 1971; 212: 299-319.

31 Smyth DH. Intestinal transfer mechanisms, measurements and analogies. J Clin Pathol 1977; 24 suppl 5: 1-9. 